\title{
Saudi Parental Involvement in EFL Students' Achievement via Edmodo
}

\author{
Areej A. Alsanosi \\ English Teacher at Alqunfodah Schools, Harb bin Essa sector, \\ Ministry of Education, Madinah, Saudi Arabia \\ E-mail: areeja.s@taibahu.edu.sa; Areeja.s@hotmail.com \\ Thuraya A. Alabsi \\ Education College, Taibah University, Madinah, Saudi Arabia \\ E-mail: tebsi@taibahu.edu.sa; t_alebsi@hotmail.com
}

Received: September 19, 2019 Accepted: November 23, 2019 Published: November 27, 2019

doi: 10.5296/ire.v8i1.15936

URL: https://doi.org/10.5296/ire.v8i1.15936

\begin{abstract}
Parental involvement is a key predictor of students' success in academic and general life. Moreover, the integration of technology has had a massive influence on the learning process and in facilitating parents' involvement. The current study aims to explore the role of parents in the achievements of English as a foreign language (EFL) learners via Edmodo, which is a platform consisting of three important main components. A descriptive method is used to conduct the research with a sample of 50 parents of female students at the intermediate stage of King Abdul Aziz private school, and using a questionnaire as an instrument. The results indicated a high level of parental involvement in supporting their daughters' progress. Moreover, parents were pleased when the teachers kept them informed about their daughters' progress in English. Communication with the school and supervision of homework had a positive effect on the quality of learning. The results revealed that parental involvement enhanced English language skills and increased learners' motivation to work hard. In addition, the study discovers the positive perception of parents regarding the use of Edmodo.
\end{abstract}

Keywords: Parental participation, EFL learners' Achievement, Edmodo, LMS (learning management system). 


\section{Introduction}

Family is the basis of community for individual learners. Learners need their parents' direct and indirect guidance regarding acceptable behavior. Parents also help in equipping their children with twenty-first-century skills that prepare the children for the future ahead of them. For example, parents develop the children's communication skills, enhance their self-directedness, and enable their critical thinking abilities, thus promoting better problem-solving skills (Gonzalez-DeHass, 2016; Pinter, 2017 ). Subsequently, schools complete the parents' building of their children's characters (Kebeci, 2006). However, schools cannot achieve this if they exclude the families' involvement (C'hristenson, Hurley, Sheridan, \& Fenstermacher, 1997; Shartrand et al., 1997). These studies confirm the requirements of Saudi Vision 2030 regarding the second strategic goal: enhancing the values and basic skills of students (Ministry of Education, 2016).

Regarding English in the Saudi context, EFL learners need both continuous follow-up from their parents and households, and technical support from their teachers at school, to enhance their achievements in learning English. Parents should encourage their children to learn languages, especially the English language, because it helps them to become global citizens of the fast-moving world we live in today. Alzaharani (2016) claims that, if parents participate in their children's English education in Saudi Arabia, they should motivate them to learn English, not only at school, but outside the EFL classroom as well. He adds that, since the English language is not the first language of Saudi Arabia, students need extra practice and support.

The concept of parental involvement encompasses a large number of parental behaviors that increase the academic success and cognitive development of learners, directly or indirectly (Gündüz, 2018). Lawson (2003) outlines four different categories of parental contribution: first, an educational environment for children at home that focuses on supporting homework from school and following up on the progress of extracurricular activities outside school; second, helping the teachers; third, enrolling children in schools that promote parent-teacher communication and creative problem-solving; and, fourth, assessing the arrangements in schools that reflect the school administrator's school restructuring strategies and modifications. Moreover, Epstein (2010) examines the parental involvement process by surveying parents in six diverse situations: training, communicating, volunteering, learning at home, decision-making, and collaborating with society. Shartrand et al. (1997) point out that teachers must develop new ways of involving parents in the learning process. However, educational institutes need to find new and more effective means of communicating with parents.

Technology is a useful tool in the learning process for teachers and students, but it could also be utilized as an effective strategy for enhancing parents' communication with schools (Palts $\&$ Kalmus, 2015). This effectively creates a remarkable change in the education process, both for teachers and students. Furthermore, the young people of this century innovatively use diverse technology, thus inspiring the description of learners as digital natives. This change gives learners opportunities to improve their English proficiency in real-life communication. Through this development of technology, it has a unique influence on parents' involvement in their teenagers' schools.

Edmodo is one of the LMS programs that facilitates parents', students', and teachers' contact via 
an online platform (Ekici, 2017). Furthermore, it provides countless features that suit the digital generation in learning a foreign language and help the teacher to manage the education process inside and outside the classroom. Moreover, Edmodo helps EFL learners to learn English at any time, in any place, from a native English speaker, without the need to travel. In addition to learning the English language, students need to practice English and the class period is not adequate for such practice. Because "practice makes perfect", Edmodo paves the way for learners to practice the English language, not just with their classmates, but also with native speakers at home (Nunan \& Richards, 2015).

As a result, school and parents should complement each other on behave. Moreover, technology creates massive changes in every area of life. The current study is going to shed light on the role of parental involvement, via Edmodo, in EFL students' achievements.

\subsubsection{The Problem}

Several studies assert that the active role of parents in schools contributes effectively to children's education. Kim \& Barrett (2019) found that there is a strong correlation between children's academic achievements and parental participation, which leads to higher grades. Other researchers mentioned that parental involvement with schools contributes to greater academic motivation (Simons-Morton \& Chen, 2009). On the other hand, EFL Saudi students have a negative attitude toward learning English language skills, lack motivation, and experience high levels of anxiety due to low self-confidence and low-quality homework (Farooq \& Soomro, 2018). The challenges mentioned above require both parents and English teachers to help and support students through communication and collaboration.

Furthermore, recent studies were conducted by Al-Mahrooqi, Denman, and Al-Maamari (2016) and Gündüz (2018) on this subject. These studies reconfirmed the necessity for parents' involvement in improving their children's educational achievements. In contrast to the traditional model of parental involvement in Saudi Arabia, individual efforts for home-schooling in the English language exist. Parents tend to rely on individualized, one-to-one education to develop a suitable language learning environment for their children. They try to create such an environment by attending training sessions in language institutes, buying devices, installing applications that are designed to help with language learning, engaging tutors, or arranging study abroad.

Moreover, some parents choose private schools instead of government or public schools in the belief that private schools offer a higher quality of English language teaching (Al-Qahtani, 2016). However, these individual efforts are inadequate. It is difficult to create a solid communication system among vital school stakeholders by using technology in the in the English classrooms of King Abdul Aziz (private sector) school.

The technology revolution in education has led to the creation of a new learning management system (LMS) that facilitates contact among the teachers themselves. Cheng and Yuen (2018) explained that LMS is a web-based learning tool that enables teachers to create online education tools and use different learning tools; for example, by distributing content, monitoring students' participation, and evaluating students' performance. In addition, LMS allows students to use communication features such as discussion panels and video conferencing. Therefore, many programs provide a social e-learning platform, such as 


\section{Ml Macrothink}

International Research in Education

ISSN 2327-5499

2020, Vol. 8, No. 1

Edmodo, Model, Google Classroom, Easy Classroom, Future Gate, and iEN National Education Portal.

According to Garrow (2009), "there is a lack of broad research on parental involvement and communication through technology, there is even less on the effects of Web-based communications on student academic success." This also applies in the Saudi context. Aldridge (2015) said that it is necessary to conduct future research that correlates academic achievement with parents' involvement through different strategies. Beecher and Buzhardt (2016) recommend more work on the use of mobile platforms to provide parents and teachers with easily-navigated and self-explanatory progress data that can be used to report their effective interactions with the students. Recently, research has explored the different impacts of parents' involvement in their children's schooling, whether by a positive attitude to learning or their indirect support for homework, on the quality of the students' outcomes ( Torres \& Castaneda-Pena, 2016).

Thus, the current study aims to investigate the role of parental involvement in female learners' achievements in the EFL classroom when using Edmodo as a platform to bridge the communication gap.

\subsubsection{Literature Review}

The concept of parental involvement in schools encompasses numerous factors that have direct or indirect effects on the students, not only in the education field, but also in their lives in general (Gündüz, 2018). Lee and Bowen (2006) shows that parents' involvement is based on the location of the activities, distinguishing three classifications of involvement: home-based, school-based, and home-school communication. Olmstead (2013) shows that "parent involvement can be either reactive or proactive." Reactive involvement in schooling consists of activities such as attending meetings, being involved in school activities, or volunteering. On the other hand, proactive involvement in children's learning consists of activities such as helping with homework, staying informed about school events, and following up on a child's progress.

To make the concept of parents' involvement clearer, several classifications and models are presented. The most well-known is Epstein's model (Epstein, 2010) and Hoover-Dempsey and Sandler's parental involvement model 1995-1997 ( Walker, Wilkins, Dallaire, Sandler, \& Hoover-dempsey, 2005). Epstein's model is divided into six categories: training, communication, volunteering, learning at home, decision-making, and collaboration with society (Epstein, 2010). However, Hoover-Dempsey and Sandler's parental involvement model focuses on the psychological perspective to clarify why parents become involved in the education of their children and how parental involvement makes an impact on the learners' outcomes on five levels, as shown in (Walker et al., 2005):

Level 1: Parents' basic involvement in decisions.

Level 2: Parents' choice of forms of involvement.

Level 3: Mechanisms of parental involvement's influence on a child's school.

Level 4: Tempering or mediating variables.

Level 5: Students' outcomes

Figure 1. clarifies the revision of the theoretical model of Hoover-Dempsey and Sandler. It 
shows the process of parental involvement.

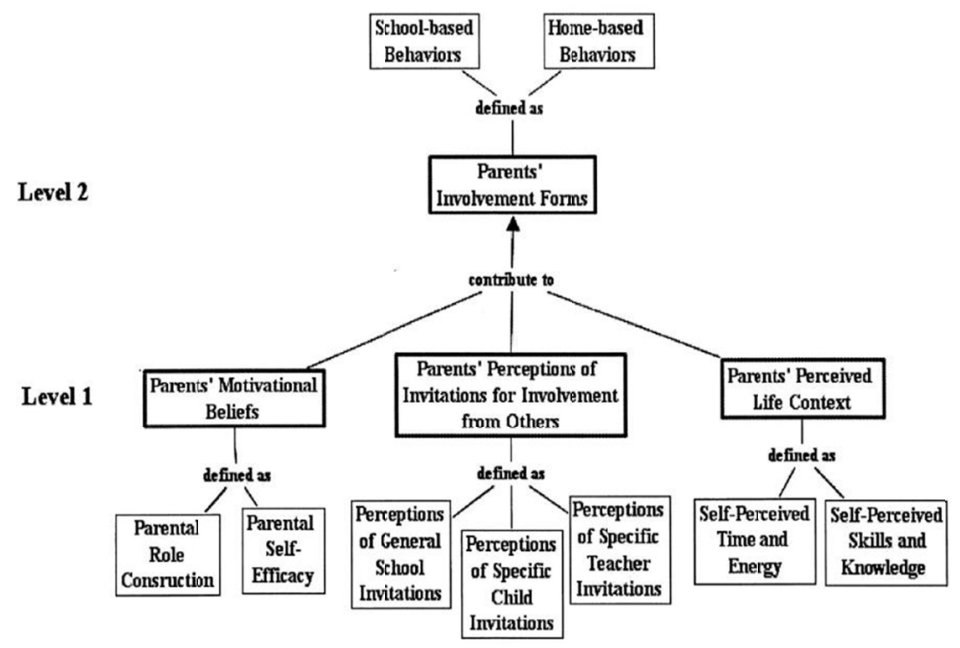

Figure 1. level 1 and 2 of Hoover-Dempsey and Sandler's $(1995,1997)$ revise the theoretical model of the parental involvement process

Source: (Walker et al., 2005).

The previous model shows how parental involvement affects the behavior of children through several factors. One of these factors is motivation, which is a result of the parents believing in their children and what they are capable of. This idea reflects the cognitive evaluation theory which will be discussed later.

Overall, Olmstead (2013) asserts that parental involvement may provide a unique source of assistance for both students and teachers. Also, parental involvement can support students in becoming more engaged in school and motivated to work harder. In addition, parents play a major role in supporting their children's education in culturally specific ways that are often invisible to school staff, by inculcating the importance of ethical behavior, hard work, and respect for teachers and peers. Parents can also encourage their children to develop essential twenty-first-century skills. Gonzalez-DeHass (2016) adds that parents can apply strategies that develop students' creativity and independence in problem-solving, self-regulation, and self-determination, which in turn lead to academic success and future professionalism.

Moreover, Protacio and Edwards (2015) remarks that "it can be a starting point for parents of ELLs English language learners to gain confidence in becoming more involved at their child's school. With a simple, feasible change to classroom practice, doors can be opened for an increased level of quality of ELLs by parental involvement" (p. 9). Parenting practices contribute to an increase in students' ability to self-regulate their behavior. Higher levels of social skills and progress in overall behavior are also documented in the study. In addition,

Children naturally acquire knowledge and develop attitudes toward concepts such as school, education and so on. Schools complete the building of knowledge and attitudes. If the school and family work together to support learning, children tend to succeed throughout life not only in school. Overall, there is a lack of consensus regarding the terminology of, and explanations for, parental involvement. For example, the terms "parental involvement," 
"family involvement," "parental engagement," "parent empowerment," and "school-family partnerships" are frequently used with different meanings in the literature. The current research uses the term "parental involvement" to encompass proactive involvement and home-school involvement. However, the distinction between this study and the previous studies is that they focus on distinctive elements in each case. For example, the English literacy of parents was taken into account as a factor that affects Turkish parents' involvement in school. The current study will shed light on the role of technology (Edmodo) on parental involvement and the extent to which EFL learners' achievements improve and English language teachers create and adapt the tool for communication between the traditional generation and digital generations.

Social psychological theories considered the effects of parental involvement such as cognitive evaluation theory, Bronfenbrenner's ecological systems theory and Connectivism Theory.

\section{Cognitive Evaluation Theory}

It was developed by psychologists Ryan and Deci (2000) as a sub-theory of self-determination, which refers to three unique psychological needs (competence, autonomy, and relatedness) that keep an individual self-motivated (Riley, 2016). Various psychological theories explain the intrinsic motivation that comes from internal rewards. The parents' role becomes vital in offering supportive education at home in order to enhance intrinsic motivation in children (Riley, 2016). Fan and Williams (2010) point out that intrinsic motivation is one of the most remarkable educational tools for a child, but simultaneously, parental involvement may lead to a decrease in the intrinsic motivation of the learner. This ambiguous issue is explained by the cognitive evaluation theory.

According to cognitive evaluation theory (Fan \& Williams, 2010), information and control are two-sided concepts that explain the effects of parental involvement on intrinsic motivation. Ames, de Stefano, Watkins, and Sheldon (1995) confirm that, when the parents receive weekly information about their children's progress, try to offer help at home, and show positive reactions to their grades, the children's intrinsic motivation is boosted. By contrast, when parents are excessively controlling, it has a negative influence on learners' motivation. Moreover, the parent-school communications concerning a student's problems may lead to demotivating discussions with the child. The child may receive negative criticism or some sort of punishment from the parents, leading to a decline in the child's confidence, interest, and engagement in learning. On the flip side, parent-school communications could lead to development in the child's study progress and parents could discuss academic growth and future academic plans with the school. This type of communication gives parents valuable information and resources with which to help their children to succeed.

\section{Bronfenbrenner's ecological systems theory}

This theory plays a substantial role in the history of parental involvement (Salwiesz, 2015). It was established and modified in the 1970s, 1980s, and 1990s through 25 experimental studies (Tudge, Mokrova, Hatfield, \& Karnik, 2009) by American psychologist, Urie Bronfenbrenner. He asserts that the ecological systems theory clarifies how human progress is influenced by diverse environmental systems (Peppler, 2017). Based on this theory, children are not only 
influenced by their own decisions, but also by contact with their family members and the world around them. It focuses on the interaction between humans and the environment (Peppler, 2017 and Salwiesz, 2015) and its effect on children's development. Sugita-McEown and McEown (2019) emphasize that the positive parental expectation and walue about English lead to Japanese students succes in learning English.

\section{Connectivism Theory}

Connectivism is a theory of technology integration in a learning process that originated from Steven Downes and George Siemens in 2005, who clearly define the natural learning that takes place between the digitally connected and socially networked worlds and is unique to the digital age (Peachey, 2017). Siemens (2005) explains that the principles of connectivism learning theory cover a variety of opinions on learning and knowledge recreation. Learning is a system of connecting specialized nodes or information sources. It may exist in non-human devices, increasing the capacity to know more than is currently known, and sustain the connections that are necessary to simplify continual learning. Continual learning is a core skill that learners need to acquire, and it is the ability to see connections between fields, ideas, and concepts. Currency (accurate, up-to-date knowledge) is the intention of all connective learning activities and decision-making and is itself a learning process. Choosing what to learn and the meaning of incoming information are seen through the lens of a shifting reality. While there is a right answer now, it may be wrong tomorrow due to changes in the information climate (Siemens, 2005). the technological influence on the new generation of learners, requires a change in the education process.

\section{EFL learners' achievement to Enhance (Home-School Contact)}

Learning through home activities allows parents to directly help their children to carry out their assignments, enhance their reading skills, choose courses and school programs, plan postsecondary education, and take advantage of other learning opportunities. As a result, the vital role of parents in considering the family and their respective culture when they are involved with the school.

In other words, when the three critical stakeholders (the school teachers, the learners, and the parents) work together, the educational outcomes may improve. Battle-Bailey (2012) conducted a study to show the effect of parents' involvement on learners' characteristics. The study finds that giving homework to students will provide them with optimal learning and will enhance home-school involvement, leading to an outstanding education. Another study confirms the effectiveness of home-school contact in the EFL classroom. Torres \& Castaneda-Pena (2016), in the context of Columbia, emphasize that parents can provide potential support for EFL learners from a non-linguistic point of view, such as by monitoring children's assignments, providing suitable learning conditions, influencing children's towards EFL by offering advice, and giving feedback on EFL homework. As a result, parents play a vital role in their children's educational lives. The parents, despite low English language proficiency, can still provide support for their children. The positive attitude of Omani parents toward involvement in schools presented in (Al-Mahrooqi et al., 2016). Parents of EFLs place a very high value on education and are involved in their children's education in significant ways, such as confirming the completion of students' homework, actively participating in parent-teacher conferences, and attending school-based parent meetings. Furthermore, 
Mahmoud (2018) shows that, in Saudi schools, parents provide support for their children in their early school years, particularly in respect of English language learning. I found that parents' involvement in the learning process directly influences their children's academic progress. This influence is directly manifested through helping with homework and projects, and indirectly by providing motivation for learning.

Studies confirm the fact that using different home-school strategies improve academic achievement. Battle-Bailey (2012) proved that ESL learners in primary school attain greater fluency in reading when they accomplish assignments with their parents. In Saudi context, Although EFL learners spend approximately six years learning English, they usually graduate from secondary school without achieving appropriate professional proficiency in the language (Al-Nasser, 2015). In addition, Saudi learners face several difficulties, such as being passive and dependent learners, lacking the initiative to learn independently, and displaying lack of motivation (Alaraj, 2016; Alrabai, 2017). Moreover, other challenges that confront EFL learners are the impact of having a different mother tongue, low exposure to English in daily life, reluctance concerning teaching and learning in English, and an absence of recent trends of EFL teaching. In addition, other challenges include the large number of EFL learners in classes, the failure to provide a creative and active environment, and lack of technology implementation in the classroom (Alrabai, 2016; Ashraf, 2018).

EFL learners typically have low achievement levels in English. According to Education First (2018), Saudi Arabia ranks eighty-third globally and eleventh in the Middle East and Africa in English proficiency. Despite all the efforts of the Saudi Ministry of Education to establish a center for improving proficiency in the English language on a national basis, Saudi EFL learners still have poor outcomes in English learning. That means that EFL learners need follow-up, cooperation, and support from their parents and teachers to enhance their achievements in English (Al-Jamal \& Al-Sharari, 2013). Parents affect the way their children develop self-confidence in using the language, by fostering a positive attitude to learning English, monitoring their homework, and motivating them to learn the language

These difficulties require considerable effort from English teachers, EFL, learners, and their parents to eliminate them and provide direct and indirect reinforcement of learning. Teachers and parents play a major role in motivating children to learn the language. Furthermore, these efforts require facilitation through the use of technology, such as Edmodo, to obtain better outcomes for EFL learners. Mokhtar (2016) asserts that using technology will provide a learning environment that is more comprehensive than traditional approaches. In other words, integrating technology with parents' and teachers' efforts will create a distinguished learning environment.

\section{Edmodo as a Platform of Parental Involvement}

Using Edmodo technology may help students to learn a new language. Edlmodo is a platform that can be utilized on both mobile devices and in the web environment to create an online community. Edmodo is a free social learning application that allows students to access the course content uploaded by their teachers (Ekici, 2017). The application provides an opportunity for teachers and students to connect via messaging, thus providing learners with the chance to connect and collaborate in a virtual classroom environment(Balasubramanian, Jaykumar, Fukey, 2014; Ekmekçi, 2016; Mokhtar, 2016). 
Edmodo is different from other social network sites since it is a sociall learning platform designed for collaboration, communication, sharing of knowledge, accessing homework assignments, and discussion between students, teachers, and parents (Balasubramanian et al., 2014). It is designed in a suitable way for the education of EFL learners.

In addition, a famous proponent of Edmodo, Kongchan (2012), suggests that collaboration in learning using Edmodo may be extended to parents. The researcher argued that it could be a secure learning platform for teachers, students, and parents. Likewise, Monalisa and Havid Ardi (2013) report that parents can also take part in their children's learning using the platform because they can check the work and progress of their children.

Furthermore, Olmstead (2013) states that, through websites, teachers can provide parents with homework, projects, and news. Parent portals provide an opportunity for parents to access students' courses, homework assignments, grades, and attendance. In addition, parents can connect with teachers via email through a direct link if they have questions about their respective students' development. Much of the research has shown that parental involvement is a key predictor of a student's academic, social, and emotional success ( Gündüz, 2018; Walker et al., 2005).

\section{Experience of EFL Learners in Edmodo}

English teachers use Edmodo in different ways, such as improving self-directed learning, motivating EFL learners, improving writing skills, et cetera. Khodary (2017) investigates the effectiveness of using Edmodo on developing self-directed learning in Saudi EFL students at the Northern Border University. The results reveal that Edmodo assists EFL learners in developing their self- directedness.

Moreover, Alshawi and Alhomoud (2016) explore the effect of using Edmodo on the motivation of EFL students and teacher-student communication at Princess Nourah Bint Abdulrahman University. The results indicate that EFL learners are motivated to learn the English language via Edmodo and students prefer to complete quizzes and submit assignments through Edmodo. The effect of conducting research may encourage teachers to integrate networking technology for educational purposes to create active learning through online classes for the students. Using Edmodo encourages both students and teachers to communicate effectively. Yusuf, Yusuf, Erdiana, and Pratama (2018) explored the impact of Edmodo on teaching the writing of narrative texts in English.

(Alshawi \& Alhomoud, 2016; Khodary, 2017) have focused on Edmodo's utilization in the learning process, including literature. Generally, in these studies, the Edmodo platform was used by students to study at various education levels. The studies took into account students' views about Edmodo. Ekmekçi (2016) revealed learners' views about using Edmodo as an assessment tool in English language classrooms. The present research corresponds with previous research in terms of Edmodo being an assessment tool for students' completion of homework, but contradicts other studies regarding the effect of integrating parental involvement through Edmodo and how this influences students' achievements.

In Saudi context, difficulties face EFL learners, such as low motivation, large class sizes, comprehension of English, and lack of technology ( Ashraf, 2018). These challenges demand concerted effort from the three stakeholders to eliminate the problem (Al-Jamal \& Al-Sharari) 
In addition, English classrooms should have sufficient access to technology.

Thereafter, Edmodo was described, and some advantages of the online platform were discussed (Kongchan, 2012). Subsequently, it exemplified some of EFL learners' experiences of Edmodo, such as Edmodo assisting EFL learners in developing their self- directedness (Khodary, 2017).

To conclude, the current study corresponds with (Gündüz, 2018; Epstein, 2010; Walker et al., 2005) in which parental involvement was shown to have a positive effect on learners' achievements. In addition, it agrees with (Battle-Bailey, 2012; Protacio \& Edwards, 2015; Torres \& Castaneda-Pena, 2016) in demonstrating that parents may affect EFL learners positively, while differing from them by focusing on parental involvement and the achievements of EFL learners at an intermediate stage, rather than a primary stage. Furthermore, it matches previous studies which concluded that it is necessary to create a channel of online communication among the three stakeholders: teachers, students and parents (Olmstead, 2013). This study will build a bridge to facilitate parental involvement through which parents can use Edmodo as a platform to follow their children's progress and enhance the learning of the English language.

\section{The Method}

In the present study, a quantitative-descriptive research method was used to gain accurate results of what parents think, say, and do, and to achieve the aim of the study. The research procedures conducted in four phases: (a) permission letter was sought to apply the instrument of the study; (b) the electronic questionnaire was sent to parents via WhatsApp; (c) the researchers spent three weeks collecting data from parents to follow up on the responses until 50 responses were received; and (d) the achievement results of EFL learners were determined.

The questionnaire was distributed electronically, and the collected data were analyzed statistically using SPSS (version 23). Descriptive statistics - as frequencies, means, standard deviations, and rank - were obtained and analyzed.

\subsection{Sample}

This study was implemented by selecting a purposive sample from King Abdul Aziz School in Al-Madinah Al-Munawara because the school applies Edmodo as a platform that gathers three groups: English teachers, EFL learners, and EFL learners' parents. The total number of parents at the intermediate stage was 190 . Of those, 50 showed involvement during the 2018 2019 academic year. This sample included 19 (38\%) students at the 1st intermediate stage, followed by $17(34 \%)$ at the 3rd intermediate stage, and $14(28 \%)$ at the 2nd intermediate stage. Furthermore, most of the students $23(46 \%)$ were at level A, while $16(32 \%)$ were at level B, and only $11(22 \%)$ were at level C. The majority of the parent participants were married (48; 96\%), while only $2(4 \%)$ were divorced. Of the 50 parents, 31(62\%) were mothers, and 19 (38\%) were fathers. Regarding age, 24 (48\%) were less than 40 years of age, $24(48 \%)$ were between 40 and 50 years of age, and only $2(4 \%)$ were between 50 and 60 years of age. Most parents were qualified, 30 (60\%) had a bachelor's degree, $12(24 \%)$ had general education, and $8(16 \%)$ had a postgraduate degree.

Only $46(92 \%)$ of participants show interest in technology and preferred using technology in 
their children's education, whereas only $4(8 \%)$ were not interested. $28(56 \%)$ parents claimed to use Edmodo weekly, while 17 (34\%) claimed to use it monthly, and only $5(8 \%)$ claimed to use it daily.

\subsubsection{The Instrument}

The study assesses the parental involvement via a designed questionnaire which consists of three parts:

Part 1 includes an introduction, the student's name and level, and parents' demographic information including general information and technical information.

Part 2 contains 24 statements that are measured on a five-point Likert scale, 12 statements measure the Role of Parents' Involvement, and 12 statements measure using Edmodo as a Platform for Parental Involvement.

Part 3 includes an open question to participants to glean their perspective regarding both the advantages and the disadvantages of Edmodo and if they have any further suggestions.

The Cronbach's Alpha coefficient was used to measure the scale of reliability. The overall coefficients of parental involvement from the questionnaire were 0.92 which indicates that the questionnaire had great stability and reliability.

\section{Results}

In order to answer the research question concerning the role of parents' involvement on EFL learners' achievement via Edmodo as a platform of communication, descriptive statistics such as frequencies, percentage, mean, and standard deviation were calculated for all statements (Tables 10 and 11). The questionnaire was divided into two sections, the role of parental involvement, and using Edmodo as a platform of parental involvement.

Table (1) shows the general results of the first section (mean, standard deviation, and rank). The results showed the overall median was 4.08, and the overall standard deviation was 0.92 . Overall, the respondents agreed with the role of parental involvement in school. Table (1) presents the general results of the second section (mean, standard deviation, and rank). As indicated, the overall median was 3.70, and the overall standard deviation was 0.95 . Most respondents agreed on the role of parental involvement in the achievement of EFL learners using Edmodo as a platform of communication.

\subsection{The Results of the Role Parents Involvement}

Table 1. Descriptive statistics for the role parents' involvement

No Statement

\begin{tabular}{|c|c|c|c|c|c|c|c|c|c|}
\hline 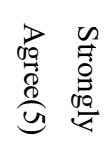 & $\begin{array}{l}\stackrel{D}{00} \\
\stackrel{0}{8} \\
\stackrel{0}{\oplus}\end{array}$ & $\begin{array}{l}z \\
z \\
0 \\
\vdots \\
0 \\
0 \\
0 \\
0\end{array}$ & 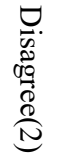 & 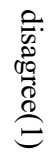 & 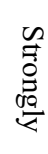 & 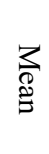 & 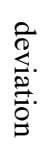 & 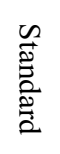 & $\begin{array}{l}\vec{\pi} \\
\text { E्रत }\end{array}$ \\
\hline
\end{tabular}

\begin{tabular}{|c|c|c|c|c|c|c|c|c|c|}
\hline \multirow{2}{*}{5} & I am satisfied when the teacher informed me & $\mathrm{N} 32$ & 15 & 3 & 0 & 0 & \multirow{2}{*}{$\begin{array}{l}4.5 \\
8\end{array}$} & \multirow{2}{*}{0.61} & \\
\hline & with my daughter progress in English. & $\% 64.0$ & 30.0 & 6.0 & 0.0 & 0.0 & & & \\
\hline \multirow{2}{*}{1} & Being contact the school affects positively on & $\mathrm{N} 13$ & 28 & 8 & 1 & 0 & \multirow{2}{*}{$\begin{array}{l}4.0 \\
6\end{array}$} & \multirow{2}{*}{0.71} & \multirow{2}{*}{2} \\
\hline & my daughter's achievement in and outside of & $\% 26.0$ & 56.0 & 16.0 & 2.0 & 0.0 & & & \\
\hline
\end{tabular}


No Statement

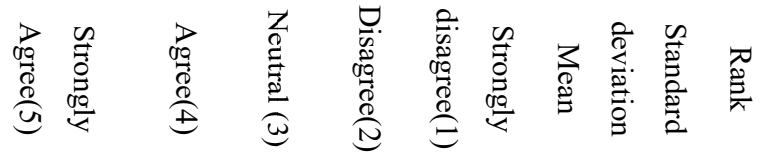

\begin{tabular}{|c|c|c|c|c|c|c|c|c|c|}
\hline & the classroom. & & & & & & & & \\
\hline \multirow{2}{*}{2} & \multirow{2}{*}{$\begin{array}{l}\text { The school provides opportunities to involve } \\
\text { me in learning English language. }\end{array}$} & $\begin{array}{ll}\mathrm{N} & 16 \\
\end{array}$ & 22 & 10 & 2 & 0 & \multirow{2}{*}{$\begin{array}{l}4.0 \\
4\end{array}$} & \multirow{2}{*}{0.83} & \multirow{2}{*}{3} \\
\hline & & $\% 32.0$ & 44.0 & 20.0 & 4.0 & 0.0 & & & \\
\hline \multirow{2}{*}{12} & \multirow{2}{*}{$\begin{array}{l}\text { I believe that my communications with school } \\
\text { enhances the quality of my daughter learning }\end{array}$} & $\mathrm{N} \quad 16$ & 21 & 10 & 3 & 0 & \multirow{2}{*}{$\begin{array}{l}4.0 \\
0\end{array}$} & \multirow{2}{*}{0.88} & \multirow{2}{*}{4} \\
\hline & & $\% 32.0$ & 42.0 & 20.0 & 6.0 & 0.0 & & & \\
\hline \multirow{2}{*}{4} & \multirow{2}{*}{$\begin{array}{l}\text { My involvement motivates my daughter to } \\
\text { work hard in English. }\end{array}$} & $\begin{array}{ll}\mathrm{N} & 16 \\
\end{array}$ & 21 & 10 & 2 & 1 & \multirow{2}{*}{$\begin{array}{l}3.9 \\
8\end{array}$} & \multirow{2}{*}{0.94} & \multirow{2}{*}{5} \\
\hline & & $\% 32.0$ & 42.0 & 20.0 & 4.0 & 2.0 & & & \\
\hline \multirow{2}{*}{10} & \multirow{2}{*}{$\begin{array}{l}\text { I help my daughter to provide extra English } \\
\text { language learning practices outside the school. }\end{array}$} & $\mathrm{N} 9$ & 26 & 9 & 5 & 1 & \multirow{2}{*}{$\begin{array}{l}3.7 \\
4\end{array}$} & \multirow{2}{*}{0.94} & \multirow{2}{*}{6} \\
\hline & & $\% 18.0$ & 52.0 & 18.0 & 10.0 & 2.0 & & & \\
\hline \multirow{2}{*}{6} & \multirow{2}{*}{$\begin{array}{l}\text { I can contact regularly with English teacher via } \\
\text { Internet. }\end{array}$} & $\mathrm{N} 9$ & 20 & 18 & 3 & 0 & \multirow{2}{*}{$\begin{array}{l}3.7 \\
0\end{array}$} & \multirow{2}{*}{0.84} & \multirow{2}{*}{7} \\
\hline & & $\% 18.0$ & 40.0 & 36.0 & 6.0 & 0.0 & & & \\
\hline \multirow[b]{2}{*}{7} & \multirow{2}{*}{$\begin{array}{l}\text { My daughter makes better progress in English } \\
\text { language skills when I involve frequently with } \\
\text { the English teacher. }\end{array}$} & $\mathrm{N} \quad 10$ & 21 & 15 & 2 & 2 & \multirow{2}{*}{$\begin{array}{l}3.7 \\
0\end{array}$} & \multirow[b]{2}{*}{0.97} & \multirow[b]{2}{*}{7} \\
\hline & & $\% 20.0$ & 42.0 & 30.0 & 4.0 & 4.0 & & & \\
\hline \multirow{2}{*}{11} & \multirow{2}{*}{$\begin{array}{l}\text { I contact English teachers to discuss daughter's } \\
\text { academic progress. }\end{array}$} & N 6 & 26 & 14 & 1 & 3 & \multirow{2}{*}{$\begin{array}{l}3.6 \\
2\end{array}$} & 095 & 8 \\
\hline & & $\% 12.0$ & 52.0 & 28.0 & 2.0 & 6.0 & & & 0 \\
\hline 9 & I am so competent in English that I could help & $\mathrm{N} 10$ & 17 & 18 & 2 & 3 & 3.5 & 105 & 9 \\
\hline & my daughter in learning. & $\% 20.0$ & 34.0 & 36.0 & 4.0 & 6.0 & 8 & & \\
\hline 8 & The English teacher provides me with notes on & $\mathrm{N} 9$ & 18 & 13 & 7 & 3 & 3.4 & 113 & 10 \\
\hline & what they can do at home. & $\% 18.0$ & 36.0 & 26.0 & 14.0 & 6.0 & 6 & & \\
\hline 3 & The English teacher communicates regularly & $\mathrm{N} 9$ & 20 & 11 & 4 & 6 & 3.4 & 1.23 & 11 \\
\hline & with me. & $\% 18.0$ & 40.0 & 22.0 & 8.0 & $12 . .0$ & 4 & & \\
\hline $\mathrm{Ov}$ & erall mean & & & & & & $\begin{array}{l}4.0 \\
8\end{array}$ & 0.92 & - \\
\hline
\end{tabular}

From the results shown in Table 1, the range of the mean in the first section was from 4.58 to 3.44 , and the overall mean was 4.08 . The overall standard deviation was 0.89 . Therefore, the study sample response was high and of great value.

\subsection{The Results of Edmodo as a Platform of Parental Involvement}


Table 2. Descriptive statistics for using Edmodo as a platform of parental involvement

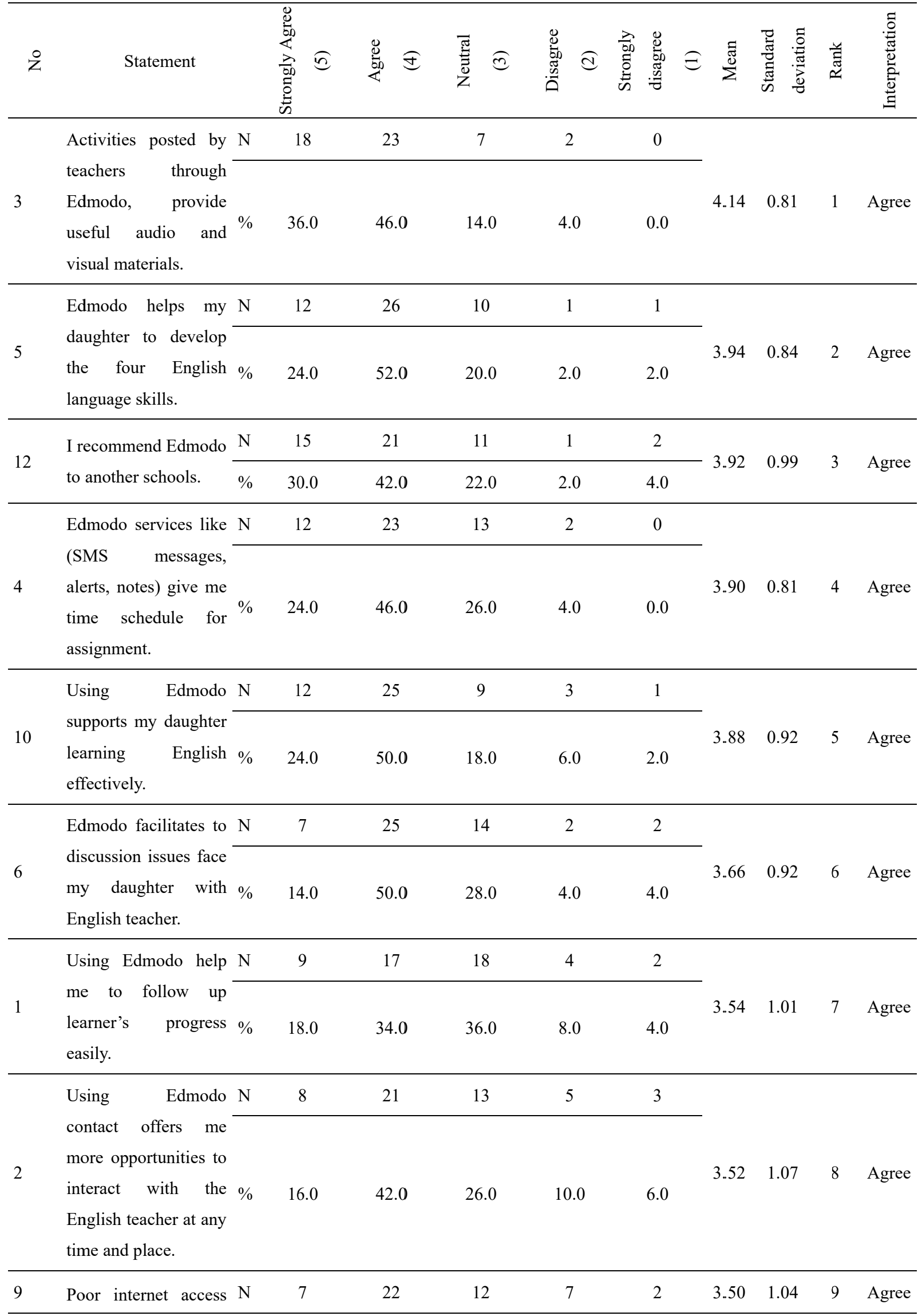




\begin{tabular}{|c|c|c|c|c|c|c|c|c|c|c|c|c|}
\hline$\stackrel{\circ}{z}$ & Statement & & 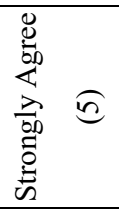 & 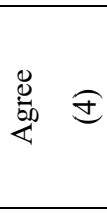 & 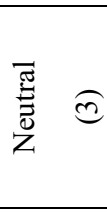 & 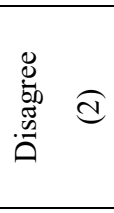 & 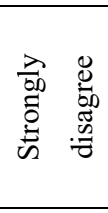 & $\widehat{Ð}$ & $\sum_{\Sigma}^{\mathbb{E}}$ & 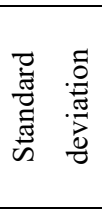 & 茹 & 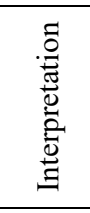 \\
\hline & $\begin{array}{l}\text { may affect following } \\
\text { up my daughter. }\end{array}$ & $\%$ & 14.0 & 44.0 & 24.0 & 14.0 & 4.0 & & & & & \\
\hline & I online & $\mathrm{N}$ & 10 & 18 & 10 & 11 & 1 & & & & & \\
\hline 11 & $\begin{array}{l}\text { communication is } \\
\text { better than face to } \\
\text { face communication. }\end{array}$ & $\%$ & 20.0 & 36.0 & 20.0 & 22.0 & 2.0 & & 3.50 & 1.11 & 9 & Agree \\
\hline & I have enough & $\mathrm{N}$ & 7 & 19 & 16 & 7 & 1 & & & & & \\
\hline 7 & $\begin{array}{l}\text { experience in using } \\
\text { Edmodo App. }\end{array}$ & $\%$ & 14.0 & 38.0 & 32.0 & 14.0 & 2.0 & & 3.48 & 0.97 & 10 & Agree \\
\hline & I am busy to follow & $\mathrm{N}$ & 4 & 24 & 15 & 5 & 2 & & & & & \\
\hline 8 & $\begin{array}{l}\text { up my daughter via } \\
\text { Edmodo. }\end{array}$ & $\%$ & 8.0 & 48.0 & 30.0 & 10.0 & 4.0 & & 3.46 & 0.93 & 11 & Agree \\
\hline \multicolumn{9}{|c|}{ Overall mean } & 3.70 & 0.95 & - & Agree \\
\hline
\end{tabular}

As Table 2 presents, the ranges of the mean for the second section were estimated to be from 4.14 to 3.46 . The overall mean was 3.70 , and the overall standard deviation was 0.95 . This indicated that the participants responded "Agree" in this section.

\subsection{Edmodo}

Moreover, the parents were requested to answer an open-ended question to explain their points of view and experiences using Edmodo freely. This was used in case further points were uncovered in their statements. Regarding the responses to this open-ended question, the parents' points of view were analyzed and categorized their responses into the following three aspects:

three aspects:

1. Advantage of Edmodo platform

a. A positive attitude toward using Edmodo

b. Awareness about exams and assignment timelines

c. Fast contact with the school to follow up on the students' progress

2. Disadvantage of Edmodo platform

a. Edmodo could only be used through a mobile phone.

b. Edmodo was a complicated platform.

c. Edmodo did not support the Arabic language.

3. Notes and suggestions

a. A parents' workshop on using Edmodo should be organized.

b. The school should follow up on the progress of Edmodo and evaluate parental 
involvement.

c. Edmodo should not nullify the parental role of visiting the school and having direct contact with the teacher.

\section{Discussion}

\subsection{The Role of Parental Involvement}

The results of the questionnaire with the school analysis indicated that the majority of parents were satisfied and liked to communicate with English teachers in the school. They believed that direct or indirect communication with the teachers had a positive impact on the learners' achievement. Similarly, these results were confirmed by Gündüz (2018), and Walker et al. (2005). These results may be classified into the following three ideas: the benefit of parental involvement, the extra practices of parental involvement, and communication.

The results of items 5, 1, 12, and 4 mainly focused on the benefit of parental involvement, including the parents' satisfaction concerning contact from the teacher, progress in academic achievement, student motivation, and the quality of learning. The high mean value of item 5 confirmed that strenuous contact between the teacher and parents satisfied the parents, as it helped them feel confident in providing answers for problems their children encountered, which supported by Protacio and Edwards (2015) Consequently, parental involvement at school affected student achievement positively because what the parents believed about their children positively influenced the children. This finding was correlated with the Hoover-Dempsey model, which stated that parental motivational belief is one of several factors that lead to academic success (Walker et al., 2005). For example, when parents show care to their children, the children want to work hard to show their parents achievement.

In this study, nearly half (44\%) of the parents agreed that the school gave them the chance to be involved in English learning. Moreover, nearly half agreed (42\%) that their communication would enhance the quality of learning because they could follow up on their children and help their children build skills that might lead to success (e.g. problem-solving, self-regulation, etc.). These results were supported by Gonzalez-DeHass (2016).

Furthermore, nearly half (42\%) of the parents believed that their involvement motivated their children to learn the English language. However, the role of parents does not only influence academic success; it starts in early childhood and expands to adulthood. Therefore, what parents believe about things (such as the importance of language) will influence the growing interests of the children. Bronfenbrenner's ecological system explains the previous idea through four systems: micro, meso, exo, and macrosystems. Through the macrosystem, the child will receive any attitude, belief, value, or psychological influences (Peppler, 2017).

Furthermore, nearly half $(42 \%)$ of parents believe that their involvement motives their daughter to learn language. The role of parents is not only based on academic success, but it started from child at early life and expand to be adult. So, what they believe about things such as the important of language, the children will grow up with these interests.

Items 10 and 9 represented extra practices of parental involvement, such as whether the parents had enough language experiences or not and whether they could help develop their children's skills (such as buying books, setting up apps for learning English, traveling abroad to practice the language, etc.). In addition, the parents' responses revealed that individual 
parental efforts to develop their children's English language existed. These corresponded with efforts found by(Al-qahtani, 2016). The most significant result was regarding the parents' English skills. The responses indicated that $36 \%$ of the parents were not sure they were skillful enough in English to assist their children. Because the parents' belief about their role more than stick into education process such as completing the homework and encouraging their children to study for exams or motivating them to get high score or discussing any challenge their children may face in the process of education as indicated in (Torres \& Castaneda-Pena, 2016).

For items 7 and 11 , nearly half ( $42 \%$ and $52 \%$, respectively) of the parents agreed that follow up on their children through frequent contact with the English teacher positively influenced the students' progress. This idea can be matched with the cognitive evaluation theory, which is concerned with intrinsic motivation as external consequence (Riley, 2016). Parental involvement and cooperation with the teacher motivate the students and contribute to academic success.

Items 2 and 6 investigated whether the school welcomed parental involvement in English through different channels such as using internet. Nearly half ( $44 \%$ and $40 \%$, respectively) of participants agreed, which reflected that teacher and parent collaboration would improve the quality of education.

\subsection{Edmodo as a Platform of Parental Involvement}

The results of using Edmodo indicated that most parents agreed to keep in touch with English teachers via Edmodo. They noted a positive effect from Edmodo on the academic progress of their children. The second section of the questionnaire showed that the majority of parents agreed to use technology to enhance their children's success in language learning. This was reflected in the overall mean (3.70) of the second section. As a result, the Edmodo platform became a channel to connect three members of the learning process (English teachers, parents, and EFL learners) to exchange experiences and save effort. Based on the study by Olmstead (2013), electronic communication enhances parental communication.

Items 3, 5, 10, and 4 confirmed that teachers were using Edmodo effectively. The platform provided appropriate materials for the EFL learners, gave direct notifications to their parents about assignments and tests, and developed parental involvement in the process of education. Furthermore, Edmodo supplied students with materials that could develop the four language skills. This result is considered one advantage of integrating parents via Edmodo; Kongchan (2012) emphasized that using Edmodo in the process of learning expanded the involvement of parents. However, the current study focused on EFL learner achievement while other studies have focused on different experiences, such as communication, writing of narrative text, and developing self-directed learning (Alshawi \& Alhomoud, 2016; Khodary, 2017). Another significant advantage of Edmodo shown in items 6,1, and 2 is that parents could contact the English teacher at any time at any place via online channels. Therefore, it was easy for them to follow up on the development of the learners and discuss any problems that the EFL learners might face.

Due to these results, the parents recommended using Edmodo in other schools. However, some participants argued that another platform might be more effective for EFL learners. In 
addition, $38 \%$ of the participants stated that online communication was better than face-to-face communication. This view showed that the popular type of parental involvement was home-school contact (Gündüz, 2018).

Some disadvantages regarding Edmodo were illustrated in items 9 and 8, which mentioned poor internet access and lack of time as two elements negatively affecting parental involvement via Edmodo. Furthermore, these results were supported by some of the responses to the open-ended question. Additionally, some emphasized that Edmodo lacked support for the Arabic language. However, the researchers found that the lack of internet access was a logical disadvantage but that the argument for lack of Arabic support revealed the parents' inexperience using technology. Whereas a critical recommendation gained from the open-ended question was that Edmodo was a useful program to facilitate communication among parents, English teachers, and EFL learners. However, it requires consistent follow up to achieve parental involvement in school. In addition, using a balanced method between electronic and traditional methods of contact represents the fundamental role of an English teacher in choosing suitable strategies and cooperative efforts to enhance parental involvement. The study showed that communication with the home school was an effective strategy of parental involvement that certainly influenced the achievement of EFL students. Furthermore, differences in parental involvement may determine the outcome of their kids' intrinsic motivation as well as the use of technology through Edmodo.

\section{Conclusion}

Saudi EFL learners may need more strategies and cooperative efforts from the English teacher and parents that support them in developing their English language skills. The present study revealed that home-school contact was a type of parental involvement that positively influenced the achievement of EFL learners. Furthermore, differences in parental involvement may determine the effect on their children's intrinsic motivation, as illustrated by the cognitive evaluation theory (Riley, 2016). Using technology such as Edmodo may become a necessary requirement of the digital generation. Parental involvement via Edmodo motivated students and made the parents more aware of task requirements. Moreover, via Edmodo, parents could discuss any critical issues facing their children in the English classroom.

Considering the above findings, several recommendations are put forward to create beneficial changes in the roles of parents of EFL learners in the Saudi context. Such as Edmodo should be used as a platform for parents' involvement, the school administration should establish support centers that provide assistance for any technical issues and create workshops for parents lacking skills in technology, curriculum designer should integrate activities that the students and their parents can accomplish together at home, and for the quality of learning, the decision-maker should give parents the opportunity to participate in strategic plans.

\section{References}

Aldridge, A. N. (2015). A Qualitative Case Study on Parental Involvement in a Midwestern Urban Charter School District: Perspectives of Parents, Teachers, and Administrators. (Doctoral dissertation). Lindenwood University by the School of Education. 
Al-Mahrooqi, R., Denman, C., \& Al-Maamari, F. (2016). Omani Parents' Involvement in Their Children's English Gündüz Education. SAGE Open, 6(1), 1-10. https://doi.org/10.1177/ 2158244016629190

Al-Nasser, A. S. (2015). Problems of English Language Acquisition in Saudi Arabia: An Exploratory-cum-remedial Study. Theory and Practice in Language Studies, 5(8), 1612. https://doi.org/10.17507/tpls.0508.10

Al-qahtani, Z. (2016). Saudi Parents' Attitudes towards Using English as a Medium of Instruction in Private Primary Schools. International Journal of Applied Linguistics and English Literature, 5(1). https://doi.org/10.7575/aiac.ijalel.v.5n.1p.18

Alshawi, S. T., \& Alhomoud, F. A. (2016). The Impact of Using Edmodo on Saudi University EFL Students' Motivation and Teacher-Student Communication. International Journal of Education, 8(4), 105. https://doi.org/10.5296/ije.v8i4.10501

Alzaharani, N. A. (2016). Saudi Students' Experiences of Learning English in English as a Foreign and Second Language Settings. Master Thesis, Mount Saint Vincent University.

Ames, C., de Stefano, L., Watkins, T., \& Sheldon, S. (1995). Teachers' School-to-Home Communications and Parent Involvement: The Role of Parent Perceptions and Beliefs. Report No. 28., 1-48. Retrieved from https://eric.ed.gov/?id=ED383451

Ashraf, T. A. (2018). Teaching English as a Foreign Language in Saudi Arabia: Struggles and Strategies. International Journal of English Language Education, 6(1), 133-154. https://doi.org/10.5296/ijele.v6i1.13148

Balasubramanian, K., Jaykumar, V., \& Fukey, L. N. (2014). A Study on "Student Preference towards the Use of Edmodo as a Learning Platform to Create Responsible Learning Environment." Procedia - Social and Behavioral Sciences, 144, 416-422. https://doi.org/10.1016/j.sbspro.2014.07.311

Battle-Bailey, L. (2012). Review of Research: Interactive Homework for Increasing Parent Involvement and Student Reading Achievement. Childhood Education, 81(1), 36-40. https://doi.org/10.1080/00094056.2004.10521292

Beecher, C., \& Buzhardt, J. (2016). Mobile technology to increase parent engagement. Interaction Design and Architectures, IxD\&A, 28, 49-68.

Cheng, M., \& Yuen, A. H. K. (2018). Student continuance of learning management system use: A longitudinal exploration. Computers and Education, 120, 241-253. https://doi.org/ 10.1016/j.compedu.2018.02.004

Education First. (2018). EF English Proficiency Index. Retrieved November 11, 2018, from https://www.ef.se/_/ /media/centralefcom/epi/downloads/full-reports/v8/ef-epi-2018-englis h.pdf

Ekici, D. I. (2017). The Use Of Edmodo in Creating an Online Learning Community Of Practice for Learning to Teach Science. Malaysian Online Journal of Educational Sciences, 5(2), 91-106.

Ekmekçi, E. (2016). Integrating Edmodo into Foreign Language Classes as an Assessment Tool. Participatory Educational Research, 16(1), 1-11. https://doi.org/10.17275/per.16.spi.1.1 


\section{Macrothink}

International Research in Education

ISSN 2327-5499

2020, Vol. 8, No. 1

Epstein, J. L. (2010). School/Family/ Community/ Partnerships: Caring for the Children We Share”. Phi Delta Kappan, Kappanmagazine.Org, 92(3), 81-96. https://doi.org/10.1177/ 003172171009200326

Fan, W., \& Williams, C. M. (2010). The effects of parental involvement on students' academic self-efficacy, engagement and intrinsic motivation. Educational Psychology, 30(1), 53-74. https://doi.org/10.1080/01443410903353302

Farooq, M. U., \& Soomro, A. F. (2018). Teachers and Technology: Trends in English Language Teaching in Saudi Arabia. International Journal of English Linguistics, 8(5), 10-19. https://doi.org/10.5539/ijel.v8n5p10

Garrow, M. S. (2009). The effects of web-based student information systems and communication on student academic success. (Doctoral dissertation), Edgewood College.

Gonzalez-DeHass, A. (2016). Preparing 21st Century Learners: Parent Involvement Strategies for Encouraging Students' Self-Regulated Learning. Childhood Education, 92(6), 427-436. https://doi.org/10.1080/00094056.2016.1251791

Gündüz, G. F. (2018). The Investigation of Parents' Interactions and Their Children's Learning Levels at Parental Coaching Carried out over Social Network. Universal Journal of Educational Research, 6(3), 491-518. https://doi.org/10.13189/ujer.2018.060315

Khodary, M. M. (2017). Edmodo Use to Develop Saudi EFL Students' Self-Directed Learning. English Language Teaching, 10(2), 123. https://doi.org/10.5539/elt.v10n2p123

Kim, J. T., \& Barrett, R. (2019). The Role of Learners' Attitudes toward Parental Involvement in L2 English Learning. English Language Teaching, 12(1), 18-29.

Kongchan, C. (2012). How a Non-Digital-Native Teacher Makes Use of Edmodo Chada. In In 5th International Conference ICT for Language Learning (pp. 1-4). Florence, Italy.

Lee, J.-S., \& Bowen, N. K. (2006). Parent Involvement, Cultural Capital, and the Achievement Gap Among Elementary School Children. American Educational Research Journal, 43(2), 193-218. https://doi.org/10.3102/00028312043002193

Mahmoud, S. S. (2018). Saudi Parents' Perceptions of the Kind of Help they Offer to their Primary School Kids. English Language Teaching, 11(3), 102. https://doi.org/10.5539/ elt.v11n3p102

Ministry of Education. (2016). National Expansion Program Work Shops. Riyadh, K.S.A.

Mokhtar, F. A. (2016). Rethinking Conventional Teaching In Language Learning And Proposing Edmodo As Intervention: A Qualitative Analysis. Malaysian Online Journal of Educational Technology (MOJET), 4(2), 22-37.

Monalisa, \& Havid, A. (2013). Using Edmodo Educational Social Network In Teaching English For High School Sudents. Journal of English Language Teaching, 2(1), 220-225. Retrieved from http://bit.do/ePCgc

Nunan, D., \& Richards, J. C. (2015). Language learning beyond the classroom. Routledge. ((Eds.), Ed.). New York: Routledge. https://doi.org/10.4324/9781315883472

Olmstead, C. (2013). Using Technology to Increase Parent Involvement in Schools. TechTrends, 57(6), 28-37. https://doi.org/10.1007/s11528-013-0699-0 
Palts, K., \& Kalmus, V. (2015). Digital channels in teacher-parent communication : The case of Estonia. International Journal of Education and Development Using Information and Communication Technology, 11(3), 65-81.

Peachey, N. (2017). Digital Tools for Teachers the Digital Classrooms Series (Trainers'). Peachey Publications.com.

Peppler, K. (2017). Ecological Systems Theory. The SAGE Encyclopedia of Out-of-School Learning. Thousand Oaks, California: SAGE Publications, Inc. https://doi.org/10.4135/ 9781483385198.n94

Protacio, M. S., \& Edwards, P. A. (2015). Restructuring sharing time for English learners and their parents. Reading Teacher, 68(6), 413-421. https://doi.org/10.1002/trtr.1327

Riley, G. (2016). The role of self-determination theory and cognitive evaluation theory in home education. Cogent Education, 3(1), 1-7. https://doi.org/10.1080/2331186X.2016. 1163651

Salwiesz, M. C. (2015). the Impact of Parent Involvement on the Education of Children: Unlocking the Role of Parent Involvement in promoting Academic Achievement Among Racially Diverse Kindergarteners. (Doctoral dissertation, Case Western Reserve University).

Siemens, G. (2005). Connectivism: A Learning Theory for the Digital Age. Journal of Instructional Technology, 1-8.

Simons-Morton, B., \& Chen, R. (2009). Peer and Parent Influences on School Engagement Among Early Adolescents. Youth \& Society, 41(1), 3-25. https://doi.org/10.1177/004411 8X09334861

Sugita-McEown, M., \& McEown, K. (2019). The role of parental factors and the self in predicting positive L2 outcomes among Japanese learners of English. Journal of Multilingual and Multicultural Development, 1-16. https://doi.org/10.1080/01434632.2019.1597874

Torres, S. A. H., \& Castaneda-Pena, H. A. (2016). Exploring the Roles of Parents and Students in EFL Literacy Learning: A Colombian Case. English Language Teaching, 9(10), 156. https://doi.org/10.5539/elt.v9n10p156

Walker, J. M. T., Wilkins, A. S., Dallaire, J. R., Sandler, H. M., \& Hoover-dempsey, K. V. (2005). Parental Involvement: Model Revision through Scale Development. The Elementary School Journal, 106(2), 1-20. https://doi.org/10.1086/499194

\section{Copyright Disclaimer}

Copyright reserved by the authors.

This article is an open-access article distributed under the terms and conditions of the Creative Commons Attribution license (http://creativecommons.org/licenses/by/3.0/). 